\title{
ЗД-15
}

\section{ВЫСВОБОЖДЕНИЕ ВИНПОЦЕТИНА ИЗ ТВЕРДЫХ ДИСПЕРСИЙ С ПОЛИВИНИЛПИРРОЛИДОНОМ}

\author{
Ю. А. Полковникова ${ }^{1}$, К. Н. Корянова ${ }^{2}$ \\ ${ }^{1}$ ФГБОУ ВО «Воронежский государственный университет», \\ 394018, г. Воронеж, ул. Студенческая, 3. \\ ${ }^{2}$ Пятигорский медико-фармачевтический институт - \\ филиал ФГБОУ ВО ВолгГМУ Минздрава России, \\ 357532, Ставропольский край, г. Пятигорск, пр. Калинина, 11 \\ E-mail: juli-polk@mail.ru
}

Разработка лекарственных препаратов с использованием поливинилпирролидона (ПВП) является перспективным направлением современной фармацевтической науке и практике, как в направлении оптимизации биофармацевтических характеристик лекарственных препаратов, создания новых лекарственных препаратов, так и совершенствования фармацевтической технологии.

Цель исследования: определить оптимальное соотношение винпоцетина и ПВП в лекарственной форме (1:2 или 1:5) по результатам моделирования молекулярной динамики высвобождения действующего вещества в водную среду.

Моделирование молекулярной динамики высвобождения винпоцетина из ПВП осуществлялось в течение 100 нс с использованием программы Gromacs 2019 в силовом поле Gromos 54a7. Параметризация фрагмента молекулы ПВП производилась с использованием интернет-сервиса Automatic Topology Builder, после чего производилась сборка молекулы полимера из 83 мономеров с использованием программы Assemble [1].

По результатам проведенных вычислительных экспериментов были рассчитаны средние значения ван-дер-ваальсовых энергий связывания винпоцетина с носителями и с растворителем, а также средняя доля молекул винпоцетина, не связанных с носителем (таблица 1).

Таблица 1. Средние значения параметров высвобождения винпоцетина из исследуемых комплексов с полимерами

\begin{tabular}{|l|c|c|c|}
\hline \multicolumn{1}{|c|}{ Система } & $\begin{array}{c}\text { Средняя энергия ван- } \\
\text { дер-ваальсова } \\
\text { взаимодействия } \\
\text { винпоцетина с } \\
\text { полимером, } \\
\text { кДж/моль }\end{array}$ & $\begin{array}{c}\text { Средняя энергия } \\
\text { ван-дер-ваальсова } \\
\text { взаимодействия } \\
\text { винпоцетина с } \\
\text { растворителем, } \\
\text { кДж/моль }\end{array}$ & $\begin{array}{c}\text { Средняя доля } \\
\text { молекул } \\
\text { винпоцетина не } \\
\text { сязанных с } \\
\text { носителем, \% }\end{array}$ \\
\hline Винпоцетин-ПВП 1:2 & $-115,85 \pm 2,68$ & $-29,88 \pm 1,32$ & $0,205 \pm 0,59$ \\
\hline Винпоцетин-ПВП 1:5 & $-160,11 \pm 2,85$ & $-25,44 \pm 2,27$ & $0,000 \pm 0,00$ \\
\hline Винпоцетин-ПВП 1:2 рН 2,0 & $-82,71 \pm 2,53$ & $-62,02 \pm 2,04$ & $11,386 \pm 1,94$ \\
\hline Винпоцетин-ПВП 1:5 рН 2,0 & $-105,57 \pm 5,10$ & $-59,47 \pm 2,77$ & $0,047 \pm 0,47$ \\
\hline
\end{tabular}

Полученные данные показывают, что высвобождение винпоцетина из ПВП в существенном количестве происходит только в кислой среде и при соотношении винпоцетина с полимером 1:2 по массе.

\section{Библиографическийсписок}

1. Definition and testing of the GROMOS force-field versions 54A7 and 54B7 / N. Schmid, A.P. Eichenberger, A. Choutko [et al.] / Eur. Biophys J. - V. 40. - 2011. - P. 843-56. 